\title{
Conclusions
}

The picture that emerges from these chapters is of two parallel normative 'forces' at work within the fields of international trade and environmental law. On the one hand, the prevailing neoliberal narrative, which emerged as a salient political force during the 1970s and, drawing from the tradition of neoclassical economics, emphasizes the superiority of free markets, deregulation, and anti-interventionism. ${ }^{1}$ This is a vision that creates a clear-cut distinction between 'trade issues', which fall under the scope of trade law, and 'non-trade issues', which are excluded from it. And even if one were to add one or more 'non-trade issues' to the trade agenda, a clear hierarchy would automatically characterize the relationship between what is 'trade' and what is not. The environment, as any other non-trade issue, would be limited to exceptions, while non-discrimination and trade liberalization would always constitute the rules of the system. It is in fact the narrative itself which defines what constitutes the rule and the exception: even when environmental components are 'added' to the trade agenda, the space they are provided is always designed as exceptional.

On the other hand, the previous chapters have unveiled a trade regime that was never meant to be only for trade liberalization and also a relationship between trade liberalization and environmental protection-as well as between the international trade and environmental regimes - that was always characterized by a synergetic nature. This nature, however, has remained largely unnoticed under the prevailing narrative. The developments described in Chapter 5 , in particular, are evidence of trade rules, procedures, and institutions that can positively contribute to the achievement of sustainable development goals, including environmental protection. A new generation of free trade agreements frames environmental protection as a rule, ${ }^{2}$ rather than

1 Narratives provide principles that guide the interpretation of a regime's rules, "suggesting answers that better fit the goals or values that rules are meant to achieve." They "capture the basic, shared understanding of why a policy is worthwhile. In the case of trade, these narratives help explain why in a political-moral sense, trade liberalization is worth pursuing. They provide a political-moral story of what trade law and policy should look like and why." See Harlan Grant Cohen, 'What is International Trade Law For?' (2019) 113(2) American Journal of International Law 326, 329. See Andrew Lang, World Trade Law After Neoliberalism. ReImagining the Global Economic Order (Oxford University Press, 2013), pp. 1-3.

2 Supra Chapter 4, Section 3. 
merely as an exception, able to be enforced on the same basis as trade rules. ${ }^{3}$ Environmental non-governmental organizations ( $\mathrm{NGO} \mathrm{s}$ ) and the civil society at large are increasingly involved in the various procedures-from the negotiation of trade agreements to the submission of amicus curiae briefs in the context of trade/environment disputes. ${ }^{4}$ And the World Trade Organization (WTO) itself is regarded, by both members of the trade and environmental community, as "the most promising" forum to deal with some of the thorniest issues at the intersection of trade and environmental law. ${ }^{5}$

The neoliberal ideas that have provided the shared normative narrative supporting the trading system since the 197os have been the object of considerable criticisms over the past 20 years, when alternative narratives have been proposed as a result of the WTO's legitimacy crisis of the late 1990s. ${ }^{6}$ Furthermore, in more recent years, the international trade regime has been struggling to cope with a whole new set of challenges, including the increasingly blurred boundaries between economic and national security, or between market and state. Many have shared their concerns about the inadequacy of the neoliberal vision to account for these new realities and about its tendency to prioritize the value of economic efficiency and the goal of economic growth to the detriment of other non-economic goals. ${ }^{7}$

3 Supra Chapter 5 , Section 2.

4 Supra Chapter 4, Section 2 and Chapter 5 , Section 2.

5 See e.g. Roberto Azevêdo, wTo Director-General, Address at the High-Level Panel on Making Trade Work for the Environment, Prosperity, and Resilience (Oct. 2, 2018); WT/CTE/M/45 (Jan. 9, 2008), para. 15 .

6 The literature is extremely rich in this regard. See e.g., Jeffrey L. Dunoff, 'Rethinking International Trade' (1998) 19(2) University of Pennsylvania Journal of International Economic Law 347; 'Death of the Trade Regime' (1999) 10(4) European Journal of International Law 733; and 'The WTO in Transition: Of Constituents, Competence, and Coherence' (2001) 33 George Washington International Law Review 979. Andrew Lang, 'The Role of the Human Rights Movement in Trade Policy-Making: Human Rights as a Trigger for Policy Learning' (2007) 5 New Zealand Journal of Public International Law 77; 'Reflecting on "Linkage": Cognitive and Institutional Change in the International Trading System' (2007) 70(4) Modern Law Review 523; and World Trade Law After Neoliberalism (n 1). Ernst-Ulrich Petersmann, 'The WTO Constitution and Human Rights' (2001) 3 Journal of International Economic Law 19; and "Time for a United Nations "Global Compact" for Integrating Human Rights into the Law of Worldwide Organizations: Lessons from European Integration' (2002) 13 European Journal of International Law 621. Susan A. Aaronson and Jamie M. Zimmerman, Trade Imbalance: The Struggle to Weigh Human Rights Concerns in Trade Policymaking (Cambridge University Press, 2008); Cohen, 'What is International Trade Law For?' (n 1). Gregory Shaffer, 'Retooling Trade Agreements for Social Inclusion' (2019) 1 University of Illinois Law Review 1.

7 See e.g. Sungjoon Cho, 'Linkage of Free Trade and Social Regulation: Moving Beyond the Entropic Dilemma' (2005) 5 Chicago Journal of International Law 626; Philip Nichols, 'Trade 
This book intends to contribute to this debate, and the interest in performing this exercise has been triggered by the analysis of the evolution of the trade/ environment nexus over the years and of the unique characteristics of the more recent developments described in Chapter 5. Such an evolution requires calling into question the prevailing narrative, which appears incapable of providing an accurate description of the nexus, and risks undermining its further development. Unlike other proposals, this book does not argue for a better balance of economic and non-economic values, for a further incorporation of non-trade issues within trade law, or for its democratization. It does not argue for a reinstatement of embedded liberalism, to better balance trade liberalization with domestic interventionism. The developments that have been observed present us with agreements and rules that do not simply allow domestic (environmental) policies but rather facilitate them. Trade liberalization and cooperation is not, in other words, simply embedded in domestic policy-making but rather instrumental to the achievement of certain legitimate policy goals.

In so doing, this book has attempted to reconceptualize the international trade regime by calling into question the prevailing 'thin' vision of the nature and purpose of trade law-largely limited to trade liberalization — which has attained something of a "natural and self-evident quality," as aptly described by Lang. ${ }^{8}$ In this spirit, this final chapter intends to continue said reconceptualization by proposing a narrative where sustainable development and environmental protection are part of the nature and purpose of trade law, rather than simply 'added to' or 'accommodated within' it. And it intends to do so by slowly pulling the thread that has been underlying the book since its very first pages.

\section{Ideational Change}

The evolution of the trade/environment nexus can be ascribed, among other factors, to the development and spreading of new ideas regarding the intersection between trade and environmental law, and the purpose of the international trade regime at large.

In the 193os, Cordell Hull was able to convincingly convey the message that "unhampered trade dovetailed with peace [while] high tariffs, trade barriers, and unfair economic conditions, with war," ${ }^{, 9}$ and his attachment to this idea

\footnotetext{
Without Values'(1996) 9o Northwestern University Law Review 658; Marco C. E. J. Bronckers, 'More Power to the WTO?' (2001) 4Journal of International Economic Law 41.

8 Lang, World Trade Law After Neoliberalism (n 1) p. 348.

9 Cordell Hull, The Memoirs of Cordell Hull (Macmillan, 1948), p. 81.
} 
was later followed by a change in collective ideas. ${ }^{10}$ The Smoot-Hawley Tariff Act of 1930 was soon associated in the public eye with the Great Depression, while multilateral cooperation to reduce tariffs came to be identified with expanding trade and increasing peaceful relations among nations. Until then, tariffs had always been regarded as a domestic concern and international trade cooperation did not seem to be in the cards until the Senator from Tennessee stepped onto the scene. Yet, despite Hull's constant efforts and calls for an international conference to kick off the process of international trade cooperation, his voice remained for a long time an isolated one. It was only after years of disappointment and setbacks that his vision for a multilateral trading system found the necessary support to become a reality.

In a not too different way, the idea that trade can be used to protect the environment was first discussed only in environmental circles. From a very early stage, environmental treaties have introduced trade-related environmental measures as means to achieve the goals they were designed for, whether to artificially control the supply of a given product, provide incentives both to join the agreement and to comply with its obligations, or ensure the integrity of the regulatory framework created with the treaty itself. To the contrary, the trade community has been arguing, in line with traditional public policy theory, that trade measures do not represent the 'best' environmental policies, ${ }^{11}$ regarding them with suspicion and framing them as 'barriers to trade.'12 It was only after several decades, in March 2019, that the Wто Secretariat commented on "the role that trade and the што could play in supporting the achievement of environmental goals," declaring that "trade could serve as a tool to disseminate and scale up environmentally sound technologies, and to accelerate the transition to a green economy."13

10 Changes in collective ideas are thought to occur whenever a policy generates "consequences for societies that deviate from their collective expectations" and that are "starkly undesirable," and when a socially plausible alternative policy exists. Jeffrey W. Legro, 'The Transformation of Policy Ideas' (2000) 44 American Journal of Political Science 419, 420,427 .

11 See e.g. Kym Anderson and Richard Blackhurst, 'Trade, the Environment and Public Policy', in Kym Anderson and Richard Blackhurst (eds.), The Greening of World Trade (University of Michigan Press, 1992).

12 See John W. Evans, The Kennedy Round in American Trade Policy: the Twilight of the GATT? (Harvard University Press, 1971); Daniel K. Tarullo, 'Logic, Myth and the International Economic Order' (1985) 26 Harvard International Law Journal 553; Judith Goldstein, 'Ideas, Institutions and American Trade Policy' (1988) 42(1) International Organization 179; and Robert Howse, 'From Politics to Technocracy-And Back Again: The Fate of the Multilateral Trading Regime' (2002) 96 American Journal of International Law 94. WT/CTE/M/66, para. 2.15. 
This statement demonstrates that the idea that not only trade, but trade rules and institutions, can play a significant role to protect the environment, is no longer limited to environmental circles, but has gained ground among the trade community and has had a direct impact on trade law- and policy-making. It was this idea that allowed the launch of multilateral trade negotiations aimed at protecting fisheries, that explained the inclusion of environmental rules in the text of trade agreements, and that motivated the recent attitudes of many states towards the nexus. And the very same idea that underlay the launch in November 2020, within the wTо, of the Structured Discussions on Trade and Environmental Sustainability, conveying the message that the Wто could and should be the place to deliver progress on issues related to trade, the environment, and sustainability. ${ }^{14}$

This process, however, has been in no way automatic or easy, just like it had not been easy for Hull to impose his multilateral vision of trade cooperation and tariff reduction at a time when contrary views prevailed. In fact, the trade policy elite, in its confidence, has been advocating and prescribing free trade as a timeless truth, monopolizing the production and authorization of legitimate policy ideas. Cognitive frameworks tend to be deeply embedded in society, and the isolated and closed nature of the trade community has made its understanding of the purpose of the trading system even more resistant to change.

Even after the environmental movement was formed and the notion of sustainable development introduced-asking all nations of the world to pursue social, economic, and environmental goals in a mutually supportive manneras long as the trade and environmental communities remained isolated, did not have access to each other's discussions, and framed their relationship on a hierarchical basis, trade rules kept being negotiated without any concern for the environment, as the trade community gave precedence to free trade principles and non-discrimination norms over environmental objectives. ${ }^{15}$ Over the years, several changes have occurred in the relationship between the two communities: changes in the degree of openness of the trade community and in the degree to which the trade and environmental communities are interconnected through actual linkages; changes in the level of formality of such linkages, in the hierarchical relationship between them; and in the degree to which their institutional arrangements and venues are integrated. ${ }^{16}$ All these factors have

14 Sofía Baliño, 'Trade and Environment Structured Discussions among WTO Member Group Get Underway', IISD Policy Brief (Mar. 10, 2021), available at http://sdg.iisd.org/ commentary/policy-briefs/trade-and-environment-structured-discussions-among-wtomember-group-get-underway/ (last accessed Mar. 26, 2021).

15 See supra Chapter 3.

16 See supra Chapter 4, Section 2 and Chapter 5 , Section 3. 
contributed to the creation of an environment far more conducive to learning than it used to be during the years of the General Agreement on Tariffs and Trade (GATT) and the first years of the wто. The two communities have started to have more regular access to each other's discussions and their ties have gradually become more frequent. They even started learning about each other's values and the utter incomprehension that had characterized the first decades of their coexistence began to fade. As a result, the environment started being taken in greater consideration in the context both of treaty drafting and dispute settlement. However, despite the indisputable positive steps, for a long time the integration between the two communities remained weak, with their relationship still framed in hierarchical terms. Moreover, the diverging views of developed and developing countries on nearly every trade/environment issue acted as an obstacle to substantial changes in the prevailing trade-centered stance. As a result, the trade-centered neoliberal ideas continued to prevail, leading to a regime that increasingly incorporated environmental values, but only peripherally and still relying on the traditional rule-exception scheme.

It is only more recently that more formalized and frequent interactions between the two communities, the gradual disappearance of a clear-cut hierarchy, and the convergence of environment and development interests on many fronts, have opened the door to more radical changes. The two agendas together-environment and development-have begun to allow the creation of trade instruments that act as means of implementation of sustainable development goals. Over time, the increasing engagement of environmental law voices and actors in trade debates has been providing an impetus for the evolution of ideas regarding rational and desirable trade policies. By addressing the trade/environment nexus from an environmental standpoint, the environmental community has prompted reflection on the broader goals and values that the trading system is designed to achieve, opening discussions on the very meaning of the ideas of 'free trade' and 'trade liberalization.'.17

17 Lang, 'Reflecting on "Linkage"' (n 6), 525 and 539. For a long time, outsiders have also refrained from discussing the meaning of 'free trade', as pointed out by Driesen. See David M. Driesen, 'What is Free Trade? The Real Issue Lurking Behind the Trade and Environment Debate' (2001) 41 Virginia Journal of International Law 279, 281; Dunoff, 'Rethinking International Trade' (n 6); Steve Charnovitz, The Path of World Trade Law in the 21st Century (World Scientific, 2014). 
If men could learn from history, what lessons it might teach us! SAMUEL COLERIDGE, 1831

To describe the evolution of the trade/environment nexus, this book has been tracing, chapter after chapter, the historical unfolding of the trade and environmental regimes, thus forcing the reader to look at history. As beautifully put by Samuel Coleridge, looking at history has its own inherent importance in that it helps us develop historical awareness. This awareness does not seem to characterize the prevailing neoliberal narrative. The latter, as a matter of fact, relies on the assumption that the ideas of 'free trade' and 'trade liberalization' have fixed meanings, and the rationale of the international trade regime is timeless. The history of the international trade regime, however, shows that the meaning of both 'free trade' and 'trade liberalization' is far from fixed, and the reasons underlying the trade regime itself, are anything but timeless. ${ }^{18}$ Just like the meaning of 'free trade', the underlying narratives-intended as the shared understanding of why trade liberalization is worth pursuing and of what trade law and policy should look like and why-are not eternal. Rather, over time, different stories have been told about the meaning and purpose of the trade regime. These different stories have each materialized in the concrete rules, procedures, and institutions associated with the trading system. ${ }^{19}$

\subsection{The GATT and Embedded Liberalism}

After World War II, the idea of 'free trade' was linked to the absence of discriminatory treatment as a reaction to protectionism. In 1947, when the GATT was drafted, a strong set of shared understandings existed as to what the purpose of the trade regime was supposed to be: to ensure international stability-in the specific sense of avoiding the horrors of the two world wars ${ }^{20}$ - which was seen as a "necessary precondition of the flourishing of the social democratic welfare state." 21 The compromise between multilateralism and domestic

18 Lang, World Trade Law After Neoliberalism (n 1); Driesen, 'What is Free Trade?' (n 17).

19 Lang, 'Reflecting on "Linkage" ' (n 6) 529.

20 See e.g. Douglas A. Irwin, 'The GATT in Historical Perspective' (1995) 85 American Economic Review 323, 326. Gerard Curzon and Victoria Curzon, 'The Management of Trade Relations in the GATT', in Andrew Shonfield (ed.), International Economic Relations of the Western World, 1959-1971. Vol. 1. Politics and Trade (Oxford University Press, 1976), pp. 143, 144; Robert E. Hudec, The GATT Legal System and World Trade Diplomacy (Butterworths, 1990), p. 5 . 
interventionism has been explained through the theory of embedded liberalism, which explains the need "to devise a framework which would safeguard and even aid the quest for domestic stability without, at the same time, triggering the mutually destructive external consequences that had plagued the interwar period." 22 These shared ideas were translated into a set of legal structures and institutional forms which went on to characterize the trade regime for more than two decades. As aptly described by Ruggie in 1986, "the principle that liberalized trade is good for global welfare and international peace was readily translated by states into such norms as non-discrimination,"23 the whole idea being that discrimination against trading partners was seen as being closely linked to the very idea of protectionism. ${ }^{24}$ And the rules of the GATT (mostfavored nation rule in Article I and National Treatment in Article III) reflected such principle and norms. At the same time, the importance to strike a balance between the needs of globalization and multilateralism on the one hand, and domestic interventionism on the other, was reflected in the introduction of safety valves in the text of the Agreement, in the form of exception clauses, which were originally intended to allow the Parties to pursue certain legitimate domestic policy goals.

\subsection{The WTO and the Resurgence of Neoliberalism}

Between the Tokyo Round in 1973 and the establishment of the wTO in 1995, the international trade regime underwent a profound transformation: dispute settlement became judicialized and compulsory, ${ }^{25}$ the scope of application of the trade regime expanded and so too did its normative content. ${ }^{26}$ This fundamental transformation has been described in this book as being ascribable to two sets of factors. On the one hand, to the increasing expansion and diversity of the GATT/WTO membership, the globalization of the economy, as well

22 John G. Ruggie, 'International Regimes, Transactions and Change: Embedded Liberalism in the Postwar Economic Order' (1982) 36 International Organization 379, 393.

23 John G. Ruggie and Friederich Kratochwil, 'International Organization: A State of the Art on an Art of the State' (1986) 40(4) International Organization 753, 769.

24 As aptly noted by Howse, GATT Articles I and III were seen as a "means of preventing member states from instituting discriminatory domestic and imported products, not a mechanism for liberalization per se." Robert Howse, "The World Trade Organization 20 Years On: Global Governance by Judiciary' (2016) 27(1) European Journal of International Law 9, 14 .

25 See e.g. Arie Reich, 'From Diplomacy to Law: The Juridicization of International Trade Relations' (1997) 17 Northwestern Journal of International Law \& Business 775.

26 New rules were introduced, regulating areas that were not traditionally considered part of the 'liberal trade project' — such as technical regulations, standards, services, and intellectual property rights. 
as governments' increasing recourse to new kinds of interventions and trade restrictions to address the rampant recession and stagflation. ${ }^{27}$ On the other, to the development of the idea of 'free trade' as a synonym of freedom from burdens rather than simply freedom from discrimination, and the consequent convergence between the idea of trade barriers and that of trade distortions. ${ }^{28}$ The underlying force was the resurgence of economic liberalism in both developed and developing countries and of neoliberal ideas as the shared normative narrative underlying this transformation as well as the trade regime itself for the years that would follow.

\subsection{The 2030 Agenda and the Instrumental Role of Trade}

Over the course of the last decade, the trading system has undergone yet again a number of significant changes. Today's political, socio-economic, and cultural environment is not the same as it was when the Second World War ended or when the Uruguay Round was being negotiated. Environmental degradation, lack of access to clean and affordable water, and spreading hunger and poverty have become today as pressing concerns as ensuring peaceful inter-state relations was when American and British officials began negotiating the GATT, or driving growth and modernization was when the wTO was established. The 2030 Agenda for Sustainable Development is the result of the leaders of the world coming together to plan the best strategy to face the new challenges the world is confronted with. And in doing so, trade is depicted as an instrument, as a 'means of implementation' to address these challenges. And the developments described in the previous chapter present us with trade rules, procedures, and institutions that positively contribute to the achievement of sustainable development goals, including environmental protection. The prevailing narrative, however, does not seem able to adequately capture and explain these new developments. Thus, the final argument made in this book draws the reader's attention precisely to the need to suggest a new narrative, design a new theoretical model for the trade regime, in other words, write a 'new trade story'. ${ }^{29}$

27 The most notorious of these new types of measures were 'voluntary export restraints' trade restrictions on the quantity of a good that a country is allowed to export to another country-which were often accompanied by safeguards, balance-of-payments restrictions and other arrangements of questionable legality under the GATT.

28 As a matter of fact, any form of governmental action has a possible impact on trade. Identifying certain action as 'barriers to trade' and not others, requires a certain shared understanding of what constitutes an acceptable form of government intervention and what does not.

See Dunoff, 'Rethinking International Trade' (n 6). 
The developments presented in this book paint a picture where not only the values embodied in the trade and environmental regimes can peacefully coexist but where the interaction between the two regimes is potentially tremendously constructive: rather than focusing only on conflicts, which can and do present themselves, the focus is now on the synergies between the two fields. The prevailing narrative, however, does not seem capable to adequately capture and explain these new developments. The neoliberal narrative, in its determination of what constitutes the rule and the exception, tends to frame non-discrimination and trade liberalization as rules while the environment, as any other non-trade issue, is limited to exceptions. In fact, even when environmental components are 'added' to the trade agenda, the space they are provided is always designed as exceptional.

Many have shared their concerns about the tendency of the trade regime to prioritize the value of economic efficiency and the goal of economic growth to the detriment of other non-economic goals. In the context of these discussions, one proposal has been to 're-embed' liberalism: to reinstate, in other words, the model of embedded liberalism, where countries would retain considerable space to address social inclusion, and would be built precisely on "states' obligations to their people." ${ }^{30}$ If, on the one hand, it is true that embedded liberalism is more capable of balancing trade liberalization with domestic interventionism, and therefore trade and environmental concerns, on the other, while it made sense in the aftermath of the Second World War, it would not completely capture the recent developments described in this book. As explained by Ruggie, the theory of embedded liberalism depicts the market as 'embedded' in a broader social fabric, and multilateralism as predicated upon domestic interventionism. ${ }^{31}$ The result was the use of exception clauses so that countries could retain some space to pursue domestic social policies.

The examples provided here, on the other hand, present us with agreements and provisions that do not simply allow domestic (environmental) policies but rather facilitate them. If new trade instruments are conceived as instrumental and conducive to the achievement of environmental goals, the environment can no longer be forced into exception clauses. And in fact, these new provisions are not any longer simple safety valves, but actual rules.

\footnotetext{
$30 \quad$ Ibid., 336. See also Shaffer, 'Retooling Trade Agreements for Social Inclusion' (n 6), and Howse, 'From Politics to Technocracy' (n 12).

31 Ruggie, 'International Regimes' (n 22).
} 
Both narratives (neoliberalism and embedded liberalism) can be subsumed under what this book has defined as an exception-based model: they both frame the environment as a 'non-trade' issue to be more or less incorporated within more or less generous exception clauses. However, the developments described in the previous chapters present trade liberalization and cooperation as neither antithetical nor simply embedded in domestic policy-making, but rather as instrumental to the achievement of certain legitimate policy goals. The question is no longer how these goals might be simply accommodated within the hard-driving logic of trade, ${ }^{32}$ but rather how trade instruments can serve broader social and environmental goals. Trade liberalization and increasing countries' wealth would undoubtedly remain an important aim, but it may come second to achieving other legitimate policy goals.

This is an invitation to suspend the mainstream discourse on the relationship between trade and the environment in terms of conflicts and to put the notion of trade liberalization as the raison deetre of the trade regime into question. This means questioning trade liberalization as an undisputed assumption, showing that it is not self-evident and can be instead challenged.

\section{1}

The Trade Regime: Can't Live without It

There have been suggestions to increase the role of other organizations, or even to create an international environmental organization that could act as counterpart to the Wто. ${ }^{33}$ Although these proposals raise several important points, it can be useful to look once again at the historical development of the two regimes to assess the feasibility and desirability of this approach. One of

32 See e.g. Henrik Horn and Petros C. Mavroidis, 'The Permissible Reach of National Environmental Policies' (2008) 42(6) Journal of World Trade 1107; Gary Clyde Hufbauer et al., Global Warming and the World Trading System (Peterson Institute for International Economics, 2009); Andrew D. Mitchell and Christopher Tran, 'The Consistency of the EU Renewable Energy Directive with the wTo Agreements' (2010) 1(1) Renewable Energy Law \& Policy Review 33; Patrick Low et al., 'The Interface between the Trade and Climate Change Regimes: Scoping the Issues' (2012) 46(3) Journal of World Trade 485.

33 See e.g. Jeffrey L. Dunoff, 'Institutional Misfits: The GATT, the ICJ \& Trade-Environment Disputes' (1993) 15 Michigan Journal of International Law 1043, 1046 [Arguing that "tradeenvironment conflicts should be heard before an institution that recognizes the interdependent nature of global economic and environmental issues and that has a mandate to advance both economic development and environmental protection. This body should have ready access to the scientific and technical expertise that would enable it to resolve trade environment disputes knowledgeably. It should possess tools encourage nations to comply with its decisions. Finally, the institution should be able to look beyond the interests of the parties to a particular dispute to protect broader interests in the international economy and the global ecosystem."]. 
the main issues addressed by Maurice Strong and his 'men' in Stockholm dealt precisely with the choice of the institutional framework to produce, interpret, and apply this new body of law. The suggestions to create an international environmental organization and court were swiftly dismissed for two main reasons: first, unlike most subjects dealt by international law, the environment was not just another separate sectoral issue, but rather a system of interacting relationships that extends through all sectors of activity. Even if such organization or court had been created, they could not have avoided encountering the GATT first and the wTo later. ${ }^{34}$ Second, an institutional framework had already been created, both within and outside of the United Nations (UN), and the decision to privilege efficiency and avoid replication prevailed during the debates. Throughout the years, the trade regime had developed a strong institutional backbone, and a dispute settlement system that, despite current attacks, has been considered for decades 'the jewel in the crown' of the whole system. ${ }^{35}$ On the other hand, the environmental regime has been characterized by a certain 'softness' of its law and 'weakness' of its dispute resolution and enforcement mechanisms vis-à-vis the trade regime. ${ }^{36}$ And for all these reasons, the approach adopted in this book starts from the assumption that the trade regime can indeed provide an efficient and promising framework to achieve sustainable development goals, including their environmental component. Therefore, if the system is retooled to serve these broader goals, this is a process that can only begin by asking a different set of questions.

\subsection{Asking the Right Question}

The traditional and still prevailing approach to the trade/environment nexus has been to ask by what modalities can or should the environment-a 'nontrade' issue — be linked to the trade regime, ${ }^{37}$ assuming it can and assuming

34 See Joel P. Trachtman, 'Institutional Linkage: Transcending “Trade and ..."' (2002) 96(1) American Journal of International Law 77, 88.

35 See e.g. Joost Pauwelyn, 'WTo Dispute Settlement Post 2019: What to Expect?' (2019) 22(3) Journal of International Economic Law 297.

36 See e.g. Daniel Bodansky, The Art and Craft of International Environmental Law (Harvard University Press, 2010).

37 The literature is extremely rich on this point, see, among many other examples, Larry A. DiMatteo et al., 'The Doha Declaration and Beyond: Giving Voice to Non-Trade Concerns Within the wTo Trade Regime' (2003) 36 Vanderbilt Journal of Transnational Law 95. See also Nichols, Trade Without Values (n 7); Steve Charnovitz, 'Linking Topics in Treaties' (1998) 19 University of Pennsylvania Journal of International Economic Law 329; Jeffery Atik, 'Introductory Essay: Uncorking International Trade, Filling the Cup of International Economic Law' (2000) 15 American University International Law Review 1231; Bronckers, 'More Power to the wTo?'; Jose E. Alvarez, 'The wTo as Linkage Machine' 
it should. ${ }^{38}$ This 'linkage' approach is based on the assumption that trade and the environment belong to two separate issue areas. And, as this book has described, whenever attempts are made to 'link' the environment — or any other 'non-trade' issue - to the trade regime, a hierarchy is almost instantaneously established between what is and what is not, technically, 'trade. ${ }^{39}$ However, the developments subsumed under the promotion-based model are characterized by the absence of such a hierarchy. In the free trade agreements (FTA S) signed by the United States (US), for instance, all environmental obligations are "enforced on the same basis as the commercial provisions of our agreements - same remedies, procedures, and sanctions." 40 And these are agreements, as clearly presented in Chapter 5 , that are aimed at both expanding trade and securing markets for goods and services, and promoting sustainable development and protecting the environment, not merely because of the language of the preamble but because of the actual norms they contain and mechanisms they provide for. The use of environmental exemptions rather than exceptions represents another sign that such a hierarchy is disappearing. The US proposal to add the enactment and enforcement of environmental standards below a certain level of environmental protection to the list of 'actionable subsidies' under the wTO subsidies agreement can be read under the same light, and so do the current negotiations on fisheries.

As an alternative, we could start asking a different question: what does the 'trade' substantive issue area include? Descriptively, defining the scope of an issue area would require observing state practice and the actual content of trade agreements and rules. As summarized by David Leebron in the context of a Symposium organized by the American Journal of International Law precisely on the topic of 'linkage', "the issue area of trade, for example, has evolved from the comparatively narrow conception of trade in goods (primarily limited to

(2002) 96(1) American Journal of International Law 146; Robert Wai, 'Countering, Branding, Dealing: Using Economic and Social Rights in and Around the International Trade Regime' (2003) 14 European Journal of International Law 35; Frank J. Garcia, 'The Salmon Case: Evolution of Balancing Mechanisms for Non-Trade Values in WTo', in George A. Bermann and Petros Mavroidis (eds.), Trade and Human Health and Safety (Cambridge University Press, 2003), p. 133; Chantal Thomas, 'Should the World Trade Organization Incorporate Labor and Environmental Standards?' (2004) 61 Washington \& Lee Law Review 347; Andrew T. Guzman, 'Global Governance and the WTO' (2004) 45 Harvard International Law Journal.

38 A number of scholars disagree with the idea of linkage. See e.g. Jagdish Bhagwati, 'On Thinking Clearly About the Linkage Between Trade and the Environment' (2000) 5 Environment \& Development Economics 483.

39 See e.g. Dunoff, 'Rethinking International Trade' (n 6) 383.

40 Office of the US Trade Representative, Bipartisan Agreement on Trade Policy (May 2007). 
the issues of border treatment and discrimination) to a much broader regime encompassing services, intellectual property, and many aspects of domestic regulation." ${ }^{41}$ If we consider new free trade agreements, the scope seems to have expanded even more. A 'new generation' of FTAs feature environmental principles, environmental obligations, and, in certain cases, apply to them the same remedies, procedures, and sanctions, that traditionally applied solely to their commercial provisions.

In other words, an alternative approach could entail revisiting the existing 'narrower' vision of what the scope, nature, and purpose of the trade regime is, and reconceptualizing it by taking into account the instrumentality of trade (trade is a means to an end rather than an end in itself) and the "contemporary political priorities" $^{\prime 2}$ (environmental degradation, lack of access to clean and affordable water, spreading hunger and poverty), to ensure that a wider variety of legitimate values "are upheld in a coherent and synergetic ... fashion."43 In doing so, this book aims to follow in the steps of other scholars and commentators who have emphasized the importance, even the necessity, to begin this conversation and ask this very same question. ${ }^{44}$

\subsection{An Organizing Principle for the Trade Regime}

The 'telos' of the trade regime ${ }^{45}$ in 1947 , when the GATT was drafted, was to achieve economic growth through the gradual elimination of trade barriers. And it did. Successfully. In 1995, the wт O was established, and its preamble was slightly, yet significantly, different: the emphasis shifted from 'economic growth' pure and simple to 'sustainable development.' As this book has explained, the notion of development refers to a process of transformation which is not limited to economic growth but rather combines it with broader social and cultural changes, while the dimension of sustainability brings the recognition that growth and development "must ... adhere to the physical constraints imposed

\footnotetext{
41 David W. Leebron, 'Linkages' (2002) 96(1) American Journal of International Law 5, 7.

42 Lang, 'Reflecting on "Linkage" ' (n 6) 542.

43 Cho, 'Linkage of Free Trade and Social Regulation' (n 7) 646. See also Sungjoon Cho, 'The wTo's Gemeinschaft' (2004) 56 Alabama Law Review 483.

44 Andrew Lang suggested to "re-conceptualize" the wTO, claiming that "trade lawyers must join the search for a new theoretical model of the trade regime, a new 'trade story' defining a new problematic for the trade regime to address." Cho has similarly argued that there is a need for a "new telos" for the trade regime. Lang, Reflecting on 'Linkage' (n 6) 542; Cho, 'Linkage of Free Trade and Social Regulation' ( $\mathrm{n} 7$ ).

Cho, 'Linkage of Free Trade and Social Regulation' (n 7).
} 
by ecosystems, so that environmental considerations have to be embedded in all sectors and policy areas." 46

The developments subsumed under the promotion-based model seem to go precisely in the direction of a trade regime that "is true to the preamble of the WTO."47 This is a regime where trade rules are determined so as to maximize development potential, as well as to lead to environmental protection and preservation. This is a regime that, rather than addressing the question of how to simply maximize trade and market access, is centered around the question of how to enable countries to protect the environment and achieve sustainable development goals. ${ }^{48}$

The principle of sustainable development, in its broader definition and as exemplified in all its diverse manifestations in the 17 goals contained in the Agenda 2030, could be used to summarize this universe of legitimate policy goals. ${ }^{49}$ It could be used as the organizing principle of trade agreements: rather than focusing on economic growth, trade agreements should be assessed in terms of their implications in terms of development and sustainability. ${ }^{50}$ Already in 2005, former wTo Director General Pascal Lamy stated that "sustainable development is itself the end-goal of this institution [the Wто],"51 and the very same ideas have been reaffirmed by former Director General, Roberto Azêvedo in several recent speeches. ${ }^{52}$ This 'organizing principle' could explain, for instance, the fisheries subsidies negotiations, where countries have agreed to prohibit certain types of subsidies because they harm the marine environment and, at the same time, distort trade, while providing less-developed

46 Neil Carter, The Politics of the Environment: Ideas, Activism, Policy (Cambridge University Press, 2018), p. 211.

47 Dani Rodrik, The Global Governance of Trade as is Development Really Mattered, Report submitted to the UNDP (2001).

48 Ibid. Rodrik made this point in 2002 with reference solely to the development component of sustainable development.

49 See e.g. Christina Voigt, Sustainable Development as a Principle of International Law (Martinus Nijhoff, 2009); Nico Schrijver, 'The Evolution of Sustainable Development in International Law' (2007) Collected Courses of the Hague Academy of International Law (The Hague Academy of International Law), pp. 217-412; Virginie Barral, 'Sustainable Development in International Law: Nature and Operation of an Evolutive Legal Norm' (2012) 23 European Journal of International Law 377.

$5^{\circ}$ Charnovitz argued that "the WTO can no longer be (if it ever was) merely a trade agency. The wто also has to be an environment agency," and that "environment and sustainable development are part of the purpose of the wTo." Charnovitz, The Path of World Trade Law (n 17) 472 .

51 Pascal Lamy, Address at the wTo symposium on Trade and sustainable Development within the framework of paragraph $5^{1}$ of the Doha Ministerial Declaration, Oct. 10, 2005. See e.g. Roberto Azevêdo, Address at the 2018 wTo Public Forum. 
countries with guarantees. This would represent a win-win-win scenario, which would benefit trade liberalization, sustainability, and development at the same time.

It would no longer be a matter of defining how trade law can accommodate non-trade values, but it would require revisiting the notion of 'trade' itself, and what the trade regime is for. Some scholars have proposed the reliance on the principle of sustainable development as an organizing principle of the debate, but they have largely been arguing that this principle should guide panels and the Appellate Body in their interpretation of wто norms and in the resolution of disputes, ${ }^{53}$ as this approach would allow a fairer balance between trade and environmental concerns. In the approach suggested in this book, on the other hand, it would not merely serve as a guiding principle in the interpretation of trade rules and in the settlement of trade/environment disputes, but would replace economic growth as the ultimate goal of the system, thus permeating every aspect of the nexus and the regime, including norms, rules, and procedures. It would not just allow the reduction or prevention conflicts, but it would promote synergies between trade and environmental law.

Not only would this re-conceptualization more accurately explain and capture the developments this book has described with reference to the trade/ environment nexus, but it would also facilitate future attempts to further develop the promotion-based model. Without re-thinking the purpose of the trade regime and reconceptualizing, in fact, all these efforts are unlikely to be successful, as they will keep clashing against an outdated but seemingly unwavering narrative.

Furthermore, although this work has been focusing on the trade/environment nexus, 'sustainable development' embraces other areas of regulation as well—such as labor standards or human rights — where similar developments can be seen. ${ }^{54}$ At the same time, these developments do not characterize solely

53 This approach has for instance been taken by the Appellate Body in US-Shrimps and has been adopted by investment tribunals as well when addressing disputes raised by FTA s (see Al Tamimi v. Oman). See e.g. Francesco Sindico, 'Unravelling the Trade and Environment Debate Through Sustainable Development Law Principles' (2005) European Society of International Law; Miguel A. Elizalde Carranza, 'MEAs with Trade Measures and the WTO: Aiming Towards Sustainable Development' (2007) 15 Buffalo Environmental Law Journal 43. See also Laurence Boisson de Chazournes and Makane Moïse Mbengue, 'A "Footnote as a Principle." Mutual Supportiveness in an Era of Fragmentation', in Holger P. Hestermeyer et al. (eds.), Coexistence, Cooperation and Solidarity—Liber Amicorum Rüdiger Wolfrum - Vol. II (Martinus Nijoff Publishers, 2011).

54 See e.g. Daniela Sicurelli, 'The EU as a Promoter of Human Rights in Bilateral Trade Agreements: The Case of the Negotiations with Vietnam' (2015) 11(2) Journal of Contemporary European Research 230; Cedric Ryngaert, 'EU Trade Agreements and Human 
international trade law but other areas of international economic regulations, such as international investment law. Investment tribunals have been increasingly integrating environmental considerations in their decisions, and recent international investment agreements have been introducing new and updated provisions that reflect similar developments to those outlined in this book. ${ }^{55}$ It follows that the arguments developed in this contribution can be relevant beyond the confines of the trade and environment debate. Rather, they intend to provide an analytical framework that can help better integrate sustainable development in different fields of international economic law, contributing to shaping the future of international economic law governance at large.

Rights: From Extraterritorial to Territorial Obligations' (2018) 20(3-4) International Community Law Review 374; Giovanni Gruni, 'Towards a Sustainable World Trade Law? The Commercial Policy of the European Union after Opinion 2/15 CJEU' (2018) 13 Global Trade \& Customs Journal 5 .

55 See Wolfgang Alschner and Elisabeth Tuerk, 'The Role of International Investment Agreements in Fostering Sustainable Development', in Freya Baetens (ed.), Investment Law within International Law (Cambridge University Press, 2013), p. 217-31; Makane M. Mbengue and Stefanie Schacherer, "The "Africanization" of International Investment Law: The Pan-African Investment Code and the Reform of the International Investment Regime' (2017) 18 Journal of World Investment and Trade 414; Stefanie Schacherer and Rhea T. Hoffmann, 'International Investment Law and Sustainable Development', in Markus Krajewski and Rhea T. Hoffmann (eds.), Research Handbook on Foreign Direct Investment (Edward Elgar, 2019), p. 564; Elena Cima, 'Retooling the Energy Charter Treaty for Climate Change Mitigation: Lessons from Investment Law and Arbitration' (2021) 14(2) Journal of World Energy Law and Business 75-87. 